\title{
Growth parameters and leaf biomass yield of stevia (Stevia rebaudiana, Bertoni) as influenced by different soil types of Bangladesh
}

\author{
M. M. Zaman, M. A. H. Chowdhury ${ }^{1^{*}}$ and Tanzin Chowdhury ${ }^{2}$ \\ Soil Resource Development Institute, Farmgate, Dhaka and ${ }^{1}$ Department of Agricultural Chemistry, ${ }^{2}$ Department of \\ Agronomy, Bangladesh Agricultural University, Mymensingh-2202, Bangladesh, *E-.mail: akhterbau11@gmail.com
}

\begin{abstract}
Soils of different types affect crop production according to their capability as a nutrient supplier based on plant requirement. Soil provides physical support to plant as well as supplies necessary water and nutrient elements for plant growth and development. Suitable soil for stevia cultivation in Bangladesh is yet to be identified. A high concentrate sweetness producer plant, stevia (Stevia rebaudiana Bertoni) was grown in earthen pots in some soils of Bangladesh to choose the most suitable soil/s for the growth and leaf yield of stevia. Seven soil types namely acid, calcareous, non-calcareous, charland, saline, peat and acid sulphate were used as treatments. The soils were mostly light grey in colour and clay to clay loam in texture. Bulk density, particle density and field capacity ranged from 1.24$1.45,2.20-2.58$ and $27.03-30.19 \%$, respectively. $\mathrm{pH}$, EC and organic matter content ranged from 3.90-8.00, 0.25$14.00 \mathrm{dS} \mathrm{m}^{-1}$ and $0.88-16.40 \%$, respectively. Total N, exchangeable $\mathrm{K}$, available $\mathrm{P}$ and $\mathrm{S}$ contents ranged from $0.05-$ $0.96 \%, 0.17-0.70 \mathrm{cmol} \mathrm{kg}^{-1}$ soil, 3-12 and $11-735 \mu \mathrm{g} \mathrm{g}^{-1}$ soil, respectively. Different soil types significantly influenced the growth and leaf yield of stevia. The highest values of plant height, branch and leaf number, leaf area, fresh and dry weight of leaves were obtained from the plant grown in non-calcareous soil which was identical with the plant those grown on acid soil while the lowest values of all the parameters were found from the plant grown in acid sulphate soil. Leaf biomass yield increase ranged from $16.18 \%$ in peat soil and $90.11 \%$ in non-calcareous soil over acid sulphate soil. The performance of the soils in terms of stevia leaf production was of the order non-calcareous $>$ acid $>$ calcareous $>$ charland $>$ saline $\left(4.43 \mathrm{dS} \mathrm{m}^{-1}\right)>$ saline $\left(6.08 \mathrm{dS} \mathrm{m}^{-1}\right)>\operatorname{saline}\left(8.68 \mathrm{dS} \mathrm{m}^{-1}\right)>$ peat $>$ acid sulphate soils. The overall results suggest that farmers could be advised to grow stevia either in non-calcareous soil or acid soils of Bangladesh.
\end{abstract}

Keywords: Stevia, Yield, Soil types, Bangladesh

\section{Introduction}

Stevia (Stevia rebaudiana), the nature's sweetest gift belongs to the family Asteraceae really stands out in that it has numerous health benefits (Rashid et al., 2013). It is an amazing plant from the rain forest of Amazone. Stevia is also known as by the name of sweet leaf, honey leaf, sweet herb, honey yerba etc. It is often referred to as "the sweet herb of Paraguay". There are nearly 300 species in the genus of stevia scattered all over the world. Of these, only Stevia rebaudiana contains the secret of stevioside, which makes it the sweetest herb in the world (Soejarto et al., 1982, 1983).

Stevia is a new crop and gaining much popularity among all types of sweetener users for its synthesized product, stevioside as most ideal substitute of sugar. Stevioside is 100 to 300 times sweeter than table sugar and clinically tested and frequently used by humans without any negative effect and an ideal, nonadditive sweetener for children. Due to sedentary life style, the incidence of obesity and diabetic conditions has been increasing dramatically all over the world. In Bangladesh, about 8 millions of people between 20 to 69 years have been suffering from this serious disease and increasing at an alarming pace. Huge numbers of children of 8 to 20 years old have also been suffering from this serious disease (Hasan, 2008).

Bangladesh being an agro-based country could easily introduce this plant as an industrial crop like sugarcane, sugar beet, tea or coffee and can commercially be cultivated in its relatively high land, char land, home stead area etc. as it grows well in open space having regular sun light. As a new crop, stevia to be domesticated in Bangladesh, a package regarding the soil and cultivation aspects, need to be standardized under different agro climatic conditions of the country. The cultivation of stevia has an immense scope for intensive agriculture and fits well for high return (Barathi, 2003). 
Few sporadic trials on the growth and leaf yield of stevia have been conducted both at pot and field conditions (Khanom, 2007; Nasrin, 2008 and Hasan, 2008). Recently Khan (2014) conducted few experiments on different agronomic aspects like date of planting, pruning, stem cutting etc on the growth and yield of stevia. Unfortunately no detailed study has yet been conducted on the suitability of soil for large scale cultivation of stevia in Bangladesh.

Soils of different types affect crop production according to their capability as a nutrient supplier based on plant requirement. Soil provides physical support to plant as well as supplies necessary water and nutrient elements for plant growth and development. Suitable soil for stevia cultivation in Bangladesh should be identified. Hence, the prevailing situation underscores the need for research to study the ideal soil types for the cultivation of stevia plant in Bangladesh. Looking at that the present research was carried out to choose the most suitable soil for the growth and leaf yield of stevia in Bangladesh.

\section{Materials and Methods}

The experiment was carried out in the net house of the Department of Agricultural Chemistry, Bangladesh Agricultural University, Mymensingh during March to May, 2010. Seven types of soils namely acid, calcareous, non-calcareous, charland, saline, peat and acid sulphate were collected from different locations of of Bangladesh viz Madhupur (Tangail), Ishurdi (Pabna), BAU campus (Mymensingh), Nandina (Jamalpur), Botiaghata (Khulna), Kotalipara (Gopalganj) and Chokoria (Cox's Bazar), respectively and were considered as treatments. Three saline soils of different salinity were included. Approximately $40 \mathrm{~kg}$ soils from each location were collected from $0-15 \mathrm{~cm}$ depth of selected fallow land for the experiment. The samples were made free from plant residues and other extraneous materials, air dried, ground and sieved through a $2 \mathrm{~mm}$ sieve. About $500 \mathrm{~g}$ sieved soil from each source was preserved in a polythene bag and the physical and chemical properties were analyzed following standard procedure (Page et al. 1982). As stevia is newly introduced in Bangladesh, there exists no fertilizer recommendation for this herb. Because of similarity of the leaf size, growth pattern of stevia with red amaranth, therefore, the recommended N, P, K, S, Zn and B doses were applied as basal dose @ 108, 24, 40, 6, 3 and $1 \mathrm{~kg}$ $\mathrm{ha}^{-1}$ (BARC, 2005) from Urea, TSP, MoP, gypsum, zinc sulphate and boric acid, respectively. One-third amount of urea and full doses of other fertilizers were applied during pot preparation one day before transplanting. The rest two installments of urea were applied at 20 and 40 days after planting (DAP). Eight kg processed soil was taken in each earthen pot of $23 \mathrm{~cm}$ in height with $30 \mathrm{~cm}$ diameter at top and $18 \mathrm{~cm}$ at bottom leaving $3 \mathrm{~cm}$ from the top. In vitro produced 45 day old stevia seedlings (Stevia rebaudiana Bertoni) were collected from brac biotechnology laboratory, Joydebpur, Gazipur and used for the experiment. One stevia seedling was planted in each pot during $1^{\text {st }}$ week of March, 2010. The experiment was laid out in completely randomized design (CRD) with three replications. Total number of pots was 27 (9 treatment $X 3$ replication). Intercultural operations like irrigation, soil loosening, weeding, insect pest control, removal of flowers etc. were done as and when necessary.

The crop was destructively harvested at $60 \mathrm{DAP}$, cleaned, oven dried at $60^{\circ} \mathrm{C}$ for 72 hours. Plant height, branches plant ${ }^{-1}$, leaves plant ${ }^{-1}$, leaf area plant ${ }^{-1}$, fresh and dry leaf weight of stevia were studied. Analysis of variance (ANOVA) was done following the principal of F-statistics and the mean values were separated by Duncan's Multiple Range Test (Gomez and Gomez, 1984).

\section{Results}

The physical properties of different soil types under investigation have been presented in Table 1. Results indicate that majority of the soils were light grey in colour except acid and peat soil which were reddish and blackish, respectively. Most of the soils were clay to clay loam in texture except non-calcareous and charland soil which were sandy clay loam to loam. Bulk density, particle density and field capacity varied with respect to soils and ranged from 1.24-1.45, 2.20-2.58 and 27.03-30.19\%, respectively. 
Table 1. Physical properties of different soil types of Bangladesh used for stevia cultivation

\begin{tabular}{|l|l|l|l|c|c|}
\hline Types of soil & \multicolumn{1}{|c|}{ Colour } & \multicolumn{1}{|c|}{ Texture } & $\begin{array}{c}\text { Bulk density } \\
\left(\mathrm{g} \mathrm{cc}^{-1}\right)\end{array}$ & $\begin{array}{c}\text { Particle density } \\
\left(\mathrm{g} \mathrm{cc}^{-1}\right)\end{array}$ & $\begin{array}{c}\text { Field capacity } \\
(\%)\end{array}$ \\
\hline Acid soil & Reddish & Clay & 1.25 & 2.23 & 29.88 \\
\hline Calcareous soil & Light grey & Clay loam & 1.41 & 2.50 & 28.10 \\
\hline Non calcareous soil & Light grey & Sandy clay loam & 1.45 & 2.58 & 27.03 \\
\hline Charland soil & Light grey & Loam & 1.43 & 2.54 & 27.15 \\
\hline Saline soil $\left(4.43 \mathrm{dS} \mathrm{m}^{-1}\right)$ & Light grey & Clay & 1.26 & 2.24 & 29.70 \\
\hline Saline soil $\left(6.08 \mathrm{dS} \mathrm{m}^{-1}\right)$ & Light grey & Cay & 1.24 & 2.21 & 30.19 \\
\hline Saline soil $\left(8.68 \mathrm{dS} \mathrm{m}^{-1}\right)$ & Light grey & Clay & 1.24 & 2.20 & 29.98 \\
\hline Peat soil & Blackish & Clay loam & 1.41 & 2.51 & 28.34 \\
\hline Acid sulphate soil & Light grey & Clay & 1.27 & 2.26 & 29.52 \\
\hline
\end{tabular}

Chemical properties also varied across the soils (Table 2). $\mathrm{pH}, \mathrm{EC}$ and organic matter content ranged from 3.9- 8.0, $0.25-14.00 \mathrm{dS} \mathrm{m}^{-1}$ and $0.88-16.40 \%$, respectively. Total $\mathrm{N}$, exchangeable $\mathrm{K}$, available $\mathrm{P}$ and $\mathrm{S}$ contents ranged from $0.05-0.96 \%, 0.17-0.70 \mathrm{cmol} \mathrm{kg}^{-1}$ soil, $3-12$ and $11-735 \mu \mathrm{g} \mathrm{g}^{-1}$ soil, respectively.

Table 2. Chemical properties of different soil types of Bangladesh used for stevia cultivation

\begin{tabular}{|l|c|c|c|c|c|c|c|}
\hline Types of soil & $\mathrm{pH}$ & $\begin{array}{c}\mathrm{EC} \\
\left(\mathrm{ds} \mathrm{m}^{-1}\right)\end{array}$ & $\begin{array}{c}\mathrm{OM} \\
(\%)\end{array}$ & $\begin{array}{c}\text { Total } \\
\mathrm{N}(\%)\end{array}$ & $\begin{array}{c}\text { Avail.P } \\
\left(\mu \mathrm{g} \mathrm{g}^{-1}\right)\end{array}$ & $\begin{array}{c}\text { Exch.K } \\
\left(\mathrm{cmol} \mathrm{kg}^{-1}\right)\end{array}$ & $\begin{array}{c}\text { Avail.S } \\
(\mu \mathrm{g} \mathrm{g}\end{array}$ \\
\hline Acid soil & 5.10 & 0.25 & 1.56 & 0.09 & 3.00 & 0.19 & 11.86 \\
\hline Calcareous soil & 7.50 & 1.26 & 1.42 & 0.08 & 4.82 & 0.18 & 15.75 \\
\hline Non calcareous soil & 6.70 & 0.67 & 1.80 & 0.11 & 12.00 & 0.17 & 11.00 \\
\hline Charland soil & 7.00 & 0.61 & 0.88 & 0.05 & 6.95 & 0.18 & 19.50 \\
\hline Saline soil $\left(4.43 \mathrm{dS} \mathrm{m}^{-1}\right)$ & 7.50 & 4.43 & 1.96 & 0.11 & 5.89 & 0.40 & 35.00 \\
\hline Saline soil $\left(6.08 \mathrm{dS} \mathrm{m}^{-1}\right)$ & 7.80 & 6.08 & 2.49 & 0.14 & 6.94 & 0.46 & 43.40 \\
\hline Saline soil $\left(8.68 \mathrm{dS} \mathrm{m}^{-1}\right)$ & 8.00 & 8.68 & 2.05 & 0.12 & 7.12 & 0.51 & 38.40 \\
\hline Peat soil & 5.60 & 4.10 & 16.40 & 0.96 & 3.00 & 0.70 & 641.00 \\
\hline Acid sulphate soil & 3.90 & 14.00 & 2.35 & 0.14 & 4.76 & 0.20 & 735.00 \\
\hline
\end{tabular}

Avail. $=$ Available, Exch. $=$ Exchangeable

The data pertaining to the effects of different soil types of Bangladesh on the growth, yield contributing characters and leaf yield of stevia have been presented in Table 3. The effects are described under the following heads.

Table 3. Effects of different soil types of Bangladesh on the growth, yield and yield attributes of stevia

\begin{tabular}{|l|l|l|l|l|c|c|}
\hline Soil types & $\begin{array}{c}\text { Plant } \\
\text { height } \\
(\mathrm{cm})\end{array}$ & $\begin{array}{c}\text { Branch } \\
\text { plant }^{-1} \\
(\mathrm{No})\end{array}$ & $\begin{array}{c}\text { Leaf area } \\
\text { plant }^{-1} \\
\left(\mathrm{~cm}^{2}\right)\end{array}$ & $\begin{array}{c}\text { Leaf fresh } \\
\text { weight } \\
(\mathrm{g})\end{array}$ & $\begin{array}{c}\text { Leaf dry } \\
\text { weight } \\
(\mathrm{g})\end{array}$ & $\begin{array}{c}\text { Yield increase } \\
\text { over acid } \\
\text { sulphate soil }(\%)\end{array}$ \\
\hline Acid & $88.33 \mathrm{a}$ & $8.67 \mathrm{a}$ & $1865 \mathrm{a}$ & $29.07 \mathrm{ab}$ & $7.90 \mathrm{ab}$ & 77.52 \\
\hline Calcareous & $85.67 \mathrm{ab}$ & $7.00 \mathrm{ab}$ & $1555 \mathrm{ab}$ & $26.10 \mathrm{bc}$ & $7.05 \mathrm{bc}$ & 58.43 \\
\hline Non-calcareous & $91.33 \mathrm{a}$ & $9.33 \mathrm{a}$ & $2010 \mathrm{a}$ & $31.09 \mathrm{a}$ & $8.46 \mathrm{a}$ & 90.11 \\
\hline Charland & $84.00 \mathrm{ab}$ & $6.67 \mathrm{~b}$ & $1336 \mathrm{bc}$ & $25.05 \mathrm{bc}$ & $6.79 \mathrm{bc}$ & 58.58 \\
\hline Saline $\left(4.43 \mathrm{dS} \mathrm{m}^{-1}\right)$ & $82.33 \mathrm{~b}$ & $6.33 \mathrm{~b}$ & $1181 \mathrm{bcd}$ & $23.60 \mathrm{~cd}$ & $6.41 \mathrm{~cd}$ & 44.04 \\
\hline Saline $\left(6.08 \mathrm{dS} \mathrm{m}^{-1}\right)$ & $81.00 \mathrm{bc}$ & $6.67 \mathrm{~b}$ & $1028 \mathrm{~cd}$ & $21.90 \mathrm{cde}$ & $5.99 \mathrm{cde}$ & 34.61 \\
\hline Saline $\left(8.68 \mathrm{dS} \mathrm{m}^{-1}\right)$ & $79.20 \mathrm{c}$ & $6.00 \mathrm{~b}$ & $894 \mathrm{~cd}$ & $20.19 \mathrm{def}$ & $5.49 \mathrm{def}$ & 23.37 \\
\hline Peat & $77.66 \mathrm{~d}$ & $5.67 \mathrm{c}$ & $851 \mathrm{~cd}$ & $19.10 \mathrm{ef}$ & $5.17 \mathrm{ef}$ & 16.18 \\
\hline Acid Sulphate & $75.33 \mathrm{e}$ & $5.67 \mathrm{c}$ & $712 \mathrm{~d}$ & $16.30 \mathrm{f}$ & $4.45 \mathrm{f}$ & - \\
\hline SE \pm & 1.65 & 0.32 & 95 & 0.96 & 0.26 & - \\
\hline CV(\%) & 0.67 & 1.58 & 3 & 1.36 & 1.36 & - \\
\hline
\end{tabular}

$\mathrm{SE} \pm=$ Standard error of means and $\mathrm{CV}=$ Coefficient of variance 


\section{Plant height}

Different soil types significantly influenced the height of stevia plant at harvest (Table 3). Tallest plant $(91.33 \mathrm{~cm})$ was recorded from non-calcareous soil which was statistically identical with those plants grown in acid soil $(88.33 \mathrm{~cm})$, calcareous soil $(85.67 \mathrm{~cm})$ and charland soil $(84.00 \mathrm{~cm})$ but significantly different from the plants grown in saline, peat and acid sulphate soils. The lowest height $(75.33 \mathrm{~cm})$ was recorded from the plant grown in acid sulphate soil.

\section{Branch number}

The data on the number of branches plant ${ }^{-1}$ at harvest as influenced by different soil types are presented in Table 3. Different types of soil significantly influenced the number of branches of stevia plant at harvest. Maximum number of branches plant ${ }^{-1}$ was counted from the plant grown in non-calcareous soil (9.33) which was identical with the branch number of the plant grown in acid soil (8.67) but statistically different from all those plants grown in other soils of the study. The plants grown in calcareous, charland and saline soils of $6.08 \mathrm{dS} \mathrm{m}^{-1}$ produced identical number of branches plant ${ }^{-1}$. On the other hand, the minimum number of branches plant ${ }^{-1}$ was obtained from the plants grown in acid sulphate and peat soils (5.67).

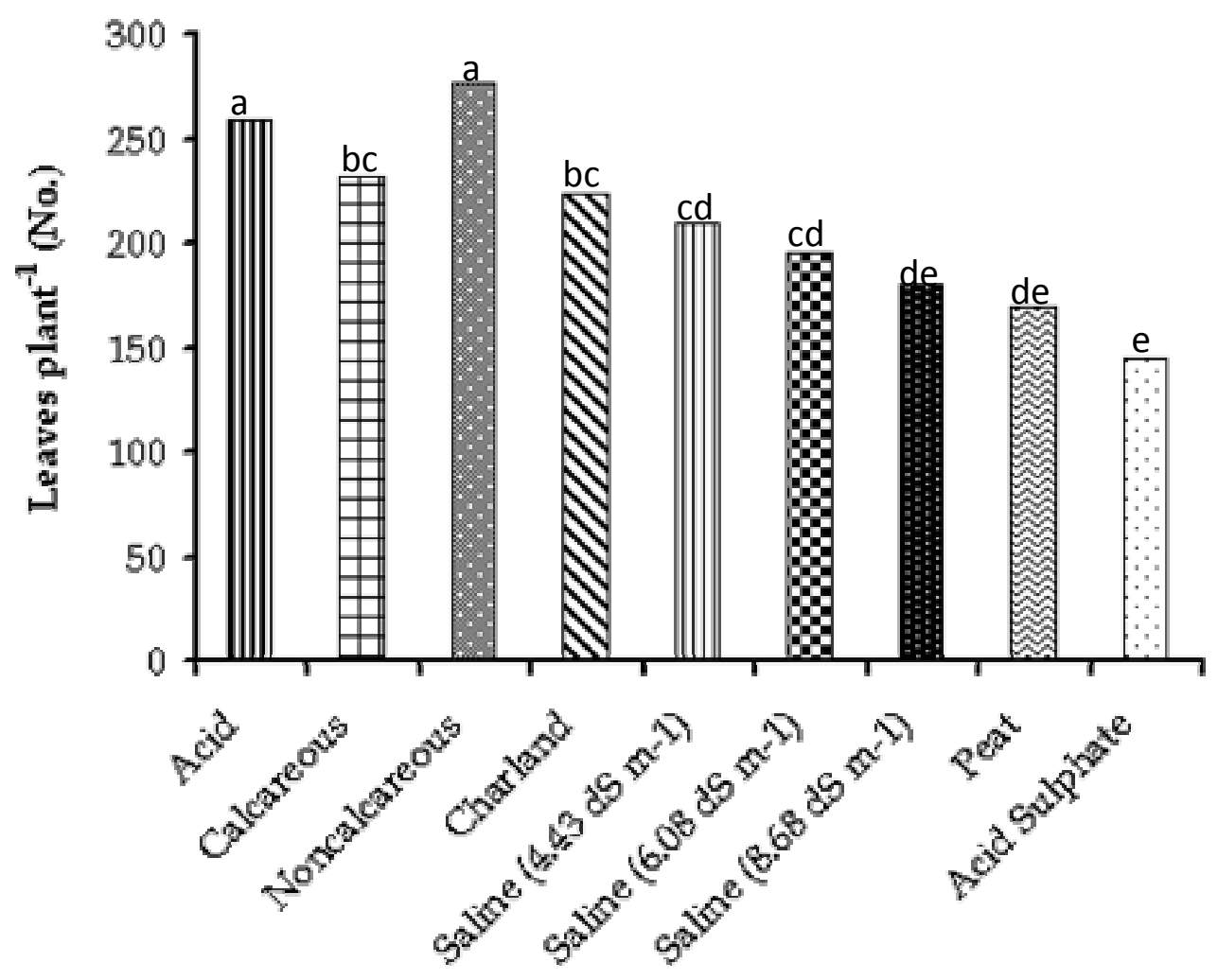

\section{Diffrent soil types}

Fig. 1. Effects of different soil types of Bangladesh on the leaf number of stevia

\section{Leaf number}

The number of leaves plant ${ }^{-1}$ at 60 days after planting (DAP) differed significantly due to the influence of different soil types of Bangladesh (Fig. 1). The highest number of leaves plant ${ }^{-1}$ was counted from the plant grown in non-calcareous soil (277) which was identical with the number of leaves of the plant grown in acid soil (259). The plants grown in acid, calcareous (232) and charland (223) soils produced identical number of leaves. Saline soils of $4.43 \mathrm{dS} \mathrm{m}^{-1}$ and $6.08 \mathrm{dS} \mathrm{m}^{-1}$ also produced identical number of leaves 
plant $^{-1}(210$ and 195 , respectively) The lowest number of leaves was harvested from the plant grown in acid sulphate soil (145) which was statistically identical with those plants grown in saline soil of $8.68 \mathrm{dS}$ $\mathrm{m}^{-1}(180)$ and peat soil (170). The performance of the soils in terms of stevia leaf production was of the following order non-calcareous $>$ acid $>$ calcareous $>$ charland $>$ saline $\left(4.43 \mathrm{dS} \mathrm{m}^{-1}\right)>$ saline $\left(6.08 \mathrm{dS} \mathrm{m}^{-1}\right)>$ saline $\left(8.68 \mathrm{dS} \mathrm{m}^{-1}\right)>$ peat $>$ acid sulphate soils.

\section{Leaf area}

The data pertaining to leaf area plant ${ }^{-1}$ at harvest as influenced by different soil types of Bangladesh are presented in Table 3 . The area of total leaves plant ${ }^{-1}$ was significantly affected by different soil types. Maximum leaf area $\left(2010 \mathrm{~cm}^{2}\right.$ plant $\left.^{-1}\right)$ was measured from the plant grown in non-calcareous soil which was statistically identical with the leaf area of the plants grown in acid $\left(1865 \mathrm{~cm}^{2}\right.$ plant $\left.{ }^{-1}\right)$ and calcareous $\left(1555 \mathrm{~cm}^{2}\right.$ plant $\left.{ }^{-1}\right)$ soils. Charland $\left(1336 \mathrm{~cm}^{2}\right.$ plant $\left.{ }^{-1}\right)$, calcareous $\left(1555 \mathrm{~cm}^{2}\right.$ plant $\left.^{-1}\right)$ and saline soil of 4.43 $\mathrm{dS} \mathrm{m}^{-1}\left(1181 \mathrm{~cm}^{2}\right.$ plant $\left.^{-1}\right)$ produced identical leaf areas plant ${ }^{-1}$. Saline soil at all levels and peat soil also produced identical leaf areas plant ${ }^{-1}$. The minimum leaf area $\left(712 \mathrm{~cm}^{2}\right.$ plant $\left.^{-1}\right)$ was obtained from the plant grown in acid sulphate soil which was identical with the plants grown in saline and peat soils.

\section{Leaf fresh weight}

The fresh weight of stevia leaves varied significantly due to the differences in soil types (Table 3). The highest leaf fresh weight $(31.09 \mathrm{~g})$ was obtained from the plant grown in non-calcareous soil which was identical with the fresh weight $(29.07 \mathrm{~g})$ of the plant grown in acid soil. The fresh weights of the plants grown in calcareous $(26.10 \mathrm{~g})$ and charland $(25.05 \mathrm{~g})$ soils were identical. The lowest fresh weight $(16.30 \mathrm{~g})$ was obtained from the plant grown in acid sulphate soil which was identical with the fresh weights of the plants grown in peat $(19.10 \mathrm{~g})$ and saline soil $(20.19 \mathrm{~g})$ of $8.68 \mathrm{dS} \mathrm{m}^{-1}$.

\section{Leaf dry weight}

Different soil types significantly influenced the dry weight of stevia leaves (Table 3). The highest leaf dry weight was obtained from the plant grown in non-calcareous soil $(8.46 \mathrm{~g})$ which was identical with the dry weight of the plant grown in acid soil $(7.90 \mathrm{~g})$. The dry weights of the plants grown in calcareous $(7.05 \mathrm{~g})$ and charland $(6.79 \mathrm{~g})$ soils were also identical. The lowest dry weight was obtained from the plant grown in acid sulphate soil $(4.45 \mathrm{~g})$ which was at par with the dry weights of the plants grown in peat $(5.17 \mathrm{~g})$ and saline soil of $8.68 \mathrm{dS} \mathrm{m}^{-1}(5.49 \mathrm{~g})$. The yield increase in dry leaf of other soils over acid sulphate soil ranged between $16.18 \%$ for the plant grown in peat soil to $90.11 \%$ for the plant of non-calcareous soil. The yield increase of the plants grown in acid, calcareous, charland, saline soil of $4.43,6.08$ and $8.68 \mathrm{dS}$ $\mathrm{m}^{-1}$ were $77.52,58.43,58.58,44.04,34.61$ and $23.37 \%$, respectively. Dry leaf yield of stevia grown in different soils of Bangladesh was of the following order non-calcareous $>$ acid $>$ calcareous $>$ charland $>$ saline $\left(4.43 \mathrm{dS} \mathrm{m}^{-1}\right)>$ saline $\left(6.08 \mathrm{dS} \mathrm{m}^{-1}\right)>$ saline $\left(8.68 \mathrm{dS} \mathrm{m}^{-1}\right)>$ peat> acid sulphate soils.

\section{Discussion}

Different soil types affect crop production according to their capability as a nutrient supplier based on plant requirement. Building healthy soil is an ongoing process, because plants can deplete the nutrients in the soil as they grow. Soil provides physical support to plant as well as supplies necessary water and nutrient elements for plant growth and development. Plant growth basically depends on the physical, chemical and biological properties of soil. Different soil types significantly influenced the yield contributing characters and leaf biomass yield of stevia at harvest. The tallest plant $(91.33 \mathrm{~cm})$, maximum number of branches plant $^{-1}$ (9.33), highest number of leaves plant ${ }^{-1}(277)$, maximum leaf area $\left(2010 \mathrm{~cm}^{2}\right.$ plant $\left.^{-1}\right)$, highest leaf fresh and dry weight $(31.09 \mathrm{~g}$ and $8.46 \mathrm{~g})$ was obtained from the plant grown in noncalcareous soil which was identical with the plant grown in acid soil. The lowest values of all the parameters were obtained from the plant grown in acid sulphate soil which was not significantly different from the plant grown in peat soil. The performance variation of different soils for stevia cultivation may be due the physical and chemical properties of the soils under investigation (Table 1 and 2). Among the properties, $\mathrm{pH}$, organic matter content, salinity, nutrient contents and their availability are the prime factors controlling the growth and yield of any crop. 
Stevia is a semi humid subtropical plant that is grown easily like any other vegetable crop (Brandle, 2004). Sandy loam soil with a slightly acidic to neutral $\mathrm{pH}$ and good drainage is important for stevia cultivation (Borie, 2005). Midore and Rank (2002) observed that stevia can also be grown on relatively poor soil. Colombus (1997) and Oddone (1999) reported that stevia can grow in low laying areas on poor sandy acidic soils adjacent to swamp. Though it grows naturally on highly acid soil of pH 4-5 but it can be cultivated well on slightly acidic to slightly alkaline soil ( $\mathrm{pH}$ 6.5-7.5). Oddone (1999) suggested that soils should be well drained but with reasonable water holding capacity and preferably with $\mathrm{pH} 5-7$, alkaline soil should be avoided.

Best performance of non-calcareous soil may be due to its moderate $\mathrm{pH}$ (6.7), less water holding capacity (27\%), soil texture (sandy clay loam). Similarly, acid soil of moderate $\mathrm{pH}$ (5.10) could be the reasons for getting better yield. Khanom (2007) cultivated stevia in four different soils of Bangladesh viz. calcareous, non-calcareous, acid and saline. She reported that non-calcareous soil was the best performer followed by acid soil for the growth and leaf yield of stevia. Calcareous soil containing high amount of lime develops in calcareous pans in the horizon having pH values 7.5 and 8.5 (Banglapedia, 2006) are responsible for the average yield of stevia. Saline soil having a high soluble salt especially sodium chloride, sodium sulphate or magnesium chloride (Khan et al., 2008) developing salinity may be the reason for its poor performance. The crop production constraints in saline soil include reduction in absorption in water and nutrients due to high osmotic pressure, poor soil structure and damage of young plants (Mukit, 2013). Shallow rooted crops like stevia are likely to be more affected. Schock (1982) noted that stevia was not adapted to water stress or saline conditions. Growth of stevia in acidic and saline soils was investigated by Lee et al. (1980). They opined that the plant should not be grown in saline soils or with poor quality water because it has little salt tolerance. It can be grown on a large scale in well drained red and sandy loam soil. The soil should have $\mathrm{pH}$ range of 6.5-7.5.

Very poor performance of peat soil may be due to its high organic matter content $(>20 \%)$ and water saturated environment (Khan et al., 2008). Organic matter may occupy up to $40 \mathrm{~cm}$ depth. Dark brown muck is the common constituent of peat soil. The limitations for crop production include deep flooding, wetness throughout the year, low bearing capacity and poor availability of K, Zn and Cu (Mukit, 2013). The poorest performance of acid sulphate soil mainly could be due to its very low $\mathrm{pH}$ (3.9). Acid sulphate soil contains iron sulphides. When sea level rise inundates land, sulphate in the sea water is mixed with land sediments containing oxides or matter. The resulting chemical reaction produces sulphuric acid for which the name acid sulphate soils (Khan et al., 2008) stand. The potential of the acid sulphate soils for crop production is severely limited by some environmental factors like saline tidal flooding, tidal bores and probability of cyclone storms. Deficiency of $\mathrm{P}$ and toxicity of Fe and Al are the major constraints for crop cultivation in acid sulphate soil (Mukit, 2013).

\section{Conclusion}

The performance of different soil types of Bangladesh for stevia cultivation was evaluated. The soils were mostly light grey in colour and clay to clay loam in texture. Bulk density, particle density and field capacity ranged from 1.24-1.45, 2.20-2.58 and 27.03-30.19\%, respectively. $\mathrm{pH}, \mathrm{EC}$ and organic matter content ranged from $3.90-8.00,0.25-14.00 \mathrm{dS} \mathrm{m}^{-1}$ and $0.88-16.40 \%$, respectively. Total $\mathrm{N}$, exchangeable $\mathrm{K}$, available $\mathrm{P}$ and S contents ranged from $0.05-0.96 \%, 0.17-0.70 \mathrm{cmol} \mathrm{kg}^{-1}$ soil, $3-12$ and $11-735 \mathrm{\mu g} \mathrm{g}^{-1}$ soil, respectively. Different soil types significantly influenced the growth and leaf yield of stevia. The tallest plant, highest branch and leaf number, leaf area, fresh and dry weight of leaves were obtained from the plant grown in non-calcareous soil which was identical with the plant of acid soil. In contrast, lowest values of all the parameters were found in the plant grown in acid sulphate soil which was at par with the plant grown in peat soil. Dry leaf yield increase ranged from 16.18 in peat soil to $90.11 \%$ in noncalcareous soil over acid sulphate soil. 


\section{Acknowledgement}

We express our sincere thanks and gratitude to the concerned authority of Bangladesh Agricultural Research Council (BARC), Farmgate, Dhaka for financial support.

\section{References}

Banglapedia 2006. National Encyclopedia of Bangladesh. A copyright Banglapedia (2006).

Barathi, N. 2003. Stevia- The calorie free natural sweetener. Natural Product Radiance 2 pp. 120-122.

BARC 2005. Bangladesh Agricultural Research Council, Soil publication no. 45, BARC, Farmgate, New airport road, Dhaka-1215.

Borie KB 2005: Sweet stevia-herbs clever plants. National gardening association. Dolt yourself. Com. R.

Brandle, J.E. 2004. FAQ-stevia, Natures, Natural low calorie sweetener. http://res2.agr.ca/procedures/ message.asp/language= E\&to=brandleje\&name=Brandle\%20Jim

Columbus, M. 1997. The Cultivation of Stevia, 'Nature's Sweetener'. Food and Rural Affairs Factsheet. Ontario Ministry of Agriculture.

Gomez, K.A. and Gomez, A.A. 1984. Statistical Procedure for Agricultural Research. $2^{\text {nd }}$ edn. International Rice Research Institute. Los Banos, Philippines. pp. 207-215.

Hasan, H.M. 2008. Agronomic management practice for the improvement of growth and yield of stevia (Stevia rebaudiana Bert.). MS Thesis. Dept. Agron., BAU., Mymensingh.

Khan, M.S., Rahman, M.M., Begum, R.A., Alam, M.K., Mondal, A.T.M., Islam, A.I. and Salahin, M.S. 2008. Problems soil of Bangladesh ,Soil science division, Bangladesh Agriculture Institute, 87, Porana Palton, Dhaka, Bangladesh. soil science publication No; 8 pp 4.

Khan M.A.R. 2014. Production technology of stevia (stevia rebaudiana) by stem cutting. PhD Thesis, Department of Agronomy, Bangladesh Agricultural University, Mymensingh

Khanom, S. 2007. Growth, leaf yield and nutrient uptake by stevia as influenced by organic and chemical fertilizers grown on various types of soil. MS Thesis. Dept. Agric. Chem., BAU, Mymensingh.

Lee, J.I., Kang, K.H., Park, H.W., Ham, Y.S. and Park, C.H. 1980. Studies on the new sweetening source plant, Stevia rebaudiana in Korea. II. Effects of fertilizer rates and planting density on dry leaf yields and various agronomic characteristics of stevia. Crop Suwon 22 138-144.

Midore, D.J. and Rank, A.H. 2002. A new rural industry-Stevia-to replace imported chemical sweetners. Rural Industries Research and Development Corporation. Publication No. W02/022. Project No. UCQ-16A.

Mukit, M.R. 2013. Agripedia series, Agri-career, $3^{\text {rd }}$ Edition. The network scientific publication, Dhaka. pp. 162-163.

Nasrin, D. 2008. Effect of nitrogen on the growth, yield and nutrient uptake by stevia. MS Thesis. Dept. Agric. Chem., BAU., Mymensingh.

Oddone, B. 1999. How to grow stevia? Guarani Botanicals, Inc.: Pawcatuck, Connecticut. 1-30.

Page AL, Miller RH and Keeney DR (eds). 1982: Method of Soil Analysis, Part-2 Chemical and Microbiological Properties, $2^{\text {nd }}$ edn., American Society of Agronomy, Inc. Madison, Wisconsin, USA.

Rashid, Z., Rashid, M., Inamullah, S., Rasool, S. and Bahar, F.A. 2013. Effect of different levels of farmyard manure and nitrogen on the yield and nitrogen uptake by stevia (Stevia rebaudiana Bertoni). African Journal of Agriculture Research 8 pp. 3941 3945.

Schock, C.C. 1982. Experimental cultivation of Rebaudia's stevia in California. University California, Davis. Agron. Prog. Rep. 122.

Soejarto, D.D., Compadre, C.M., Medon, P.J., Kamath, S.K. and Kinghorn, A.D. 1983. Potential sweetening agents of plant origin. II. Field search for sweet tasting stevia species, Economic Botany 37 71-79.

Soejarto, D.D., Kenghorn, A.D. and Farnsworth, N.R. 1982. Potential sweetening agents of plant origin. III. organoleptic evaluation of stevia leaf herbarium samples for sweetness, Journal of Natural Products 45 590-599. 